\title{
COMUNICAÇÃO INTERNA COMO POTENCIADORA DE ESTRATÉGIAS PARA O DESENVOLVIMENTO ORGANIZACIONAL: UMA ANÁLISE NA EMPRESA DE IMPORTADOS
}

\section{ARTIGO ORIGINAL}

PIANCHÃO, Marcela Maria De Sousa ${ }^{1}$

SOUSA, Márcia Soares $\mathrm{De}^{2}$

SILVA, Simone Maria Ferreira $\mathrm{Da}^{3}$

ARAÚJO, Jamille Carla Oliveira ${ }^{4}$

Pianchão, Marcela Maria De Sousa. Et al. Comunicação interna como potenciadora de estratégias para o desenvolvimento organizacional: Uma análise na empresa de importados. Revista Científica Multidisciplinar Núcleo do Conhecimento. Ano 04, Ed. 10, Vol. 07, pp. 56-79. Outubro de 2019. ISSN: 24480959, Link de acesso: https://www.nucleodoconhecimento.com.br/administracao/comunicacaointerna

\section{RESUMO}

O presente trabalho objetiva analisar como uma comunicação interna eficaz pode contribuir para o desenvolvimento das atividades com eficiência na empresa de Importados, Loja BR 316, localizada em Belém - PA. Para isto o estudo abrange

\footnotetext{
${ }^{1}$ Discente do curso de Ciências Contábeis e Administração da Escola Superior Madre Celeste- ESMAC.

2 Discente do curso de Administração da Escola Superior Madre Celeste- ESMAC.

${ }^{3}$ Discente do curso de Administração da Escola Superior Madre Celeste- ESMAC.

${ }^{4}$ Mestre em Administração, MBA Gestão contábil, perícia, auditoria e controlaria, Bacharel em Ciências Contábeis.
} 
também o fluxo que a comunicação percorre nas organizações no sentido vertical ascendente e descendente, no horizontal e no diagonal, mostrando como se dá o relacionamento na organização entre os superiores e subordinados e vice-versa, assim como a relação interdepartamental. Aborda também, a importância de se traçar estratégias para detalhar as ações previstas pela organização para atingir os seus objetivos, e o que pode ocorrer quando existe a sua falta. Como procedimento de pesquisa foi utilizado para o levantamento das informações foi uma entrevista estruturada com 15 questões, onde a gestora entrevistada respondeu-as livremente. Primeiramente, foi abordado a importância da comunicação, como acontece o seu processo, as barreiras que podem interferir na transmissão da mensagem, o feedback como ferramenta de avaliação e o retorno da mensagem, como a comunicação empresarial pode ser eficiente e eficaz, e finalizando com o que a empresa sugere para melhorar a comunicação interna da organização. Percebeu-se na pesquisa que, o bom relacionamento parte de uma comunicação efetiva, da maneira que se transmite as informações e no planejamento do processo de transmissão dessas informações. Ficou claro que uma comunicação eficaz é importante para o relacionamento dos colaboradores, trazendo benefícios para a organização, melhorando a rotina de trabalho, a qualidade e a produtividade na empresa.

Palavras-chave: Comunicação interna, ferramenta, estratégia, organização, desenvolvimento.

\section{INTRODUÇÃO}

Atualmente as empresas modernas vêm evidenciando uma procura cada vez maior por profissionais que, além da capacidade de planejar, motivar, tenham principalmente, uma forma especial de transmitir uma informação, criando assim, um clima favorável para o crescimento da organização. Portanto, uma comunicação adequada, faz toda a diferença para quem deseja enfrentar novos desafios no mercado de trabalho, pois um bom comunicador sempre será alvo na empresa quando surgir uma promoção interna (LUPETTI, 2007). 
A comunicação é uma ferramenta extraordinária de poder nas gestões empresariais, pois favorece desenvolvimento das organizações, impulsionando seus colaboradores na conquista de melhores resultados. Portanto, ela deve ser planejada de maneira estratégica, para atender as necessidades dos gestores, clientes e colaboradores da organização, proporcionando assim um ambiente mais agradável, onde as informações tendem a fluir mais positivamente.

A comunicação interna além de proporcionar um maior envolvimento dos colaboradores com o seu trabalho e com os próprios colegas, também faz com que eles ampliem sua visão em relação à empresa. A partir do momento em que o funcionário conhece melhor a empresa onde trabalha e qual o papel que deve desempenhar dentro dela, ele passa a exercer suas funções com mais eficiência e uma maior produtividade (CASADO, 2002).

Na educação, o processo de comunicação é a base para a efetivação do aprendizado. Visto que, a comunicação necessita dos artifícios educacionais para aumentar seu entendimento e assim melhorar a recepção e transmissão da mensagem. Percebe-se então que, para a educação, principalmente acadêmica, a comunicação é sem dúvida um dos aspectos mais importantes, necessários e inerentes para a formação do indivíduo, e que, embora ambas sejam distintas, tornam-se inseparáveis. Sendo assim, há total relevância dessa relação e interação, pois a educação é fundamentalmente um processo de comunicação e de informação (CHIAVENATO, 2014).

No contexto regional, a comunicação exerce um papel marcante em relação às questões ambientais, que vão desde a simples tarefa informativa, até as mais complexas atribuições de auxílio à fiscalização e controle da preservação do ambiente, destacando-se nas diversas áreas da vida pública como a política, a economia e a cultura. Dessa forma, a comunicação pode traduzir, informar e conscientizar a população em geral da atual relevância da região, fator essencial para a conscientização dos diversos públicos envolvidos no processo, tornando-se assim, uma teia de conhecimentos, que auxiliam decisões sobre o presente e o futuro da região, influenciando desse modo o seu desenvolvimento. 
Todavia, uma comunicação ineficaz é um dos grandes problemas que atingem a administração das organizações. Ter uma boa comunicação é essencial nas atividades coletivas, sendo uma ferramenta básica para uma equipe trabalhar com eficiência e eficácia.

Frente às reflexões iniciais, este estudo se propõe a entender as ações realizadas pela empresa de Importados, Loja BR 316 - PA, levantando a seguinte problemática: Como uma comunicação eficaz pode contribuir para que os colaboradores desenvolvam suas atividades em busca do desenvolvimento organizacional?

O objetivo geral, deste estudo foi analisar como uma comunicação interna eficaz pode contribuir para o desenvolvimento das atividades com eficiência na empresa de Importados, Loja BR 316, localizada em Belém - PA.

Atualmente a comunicação interna, vem ganhando espaço cada vez mais no cotidiano das organizações, como um artefato crucial nas tomadas de decisões empresariais. Uma comunicação interna eficaz, pode ser o diferencial que a organização necessita, pois fortalece o relacionamento com seus colaboradores.

\section{REFERENCIAL TEÓRICO}

\subsection{COMUNICAÇÃO}

O ato de comunicar é essencial para qualquer indivíduo. Torna-se um fato tão comum no dia a dia que, muitas vezes, não se pensa ou reflete na forma como se fala ou a respeito do que se diz. A comunicação é a forma como as pessoas se relacionam entre si, dividindo e trocando experiências, ideias, sentimentos, informações, modificando mutuamente a sociedade onde estão inseridas. Serve para partilhar emoção, sentimento e informação.

Segundo Manesco (2013), desde a Pré-História, entre 500.000 A.C. e 18.000 A.C, quando os homens começaram a viver em sociedade, passaram a entender o poder e a importância da comunicação, desenvolvendo linguagens através de sons, gestos, cores e desenhos. Mas o foco principal era transmitir uma mensagem e ser entendida. 
Hoje, porém, transmitir uma mensagem é muito mais que isso, é criar um ambiente comum, criar uma imagem positiva para a empresa, possibilitando melhor interação entre as partes envolvidas.

A história da comunicação remonta à história da humanidade. A linguagem dos gestos e as primeiras manifestações da linguagem oral proporcionaram a liberdade das mãos para outras atividades culturais do ser humano - como o desenho das cavernas -, criando, assim um ciclo de desenvolvimento e de comunicação. [...]. (LUPETTI, 2007, p.14)

Nota-se que a história da comunicação, permeia a história da própria humanidade e do processo evolutivo humano. Pois antes da fala existir, os homens primitivos se comunicavam através de uma linguagem rudimentar desenvolvida por meio de gestos, desenhos, sons e expressões, revelando que, a comunicação embora rústica, já acontecia claramente.

A comunicação é um componente fundamental da condição humana. Pois cada vez que uma pessoa se comunica, ela reafirma sua condição de ser, tais como capacidade de expressões, raciocínio, compreensões e emoções (MAXIMIANO, 2010).

Idalberto Chiavenato (2014, p. 206), afirma que "A palavra comunicação provém do latim comunis, que significa tornar comum. "Por esse motivo, ao comunicar-se, constitui-se com alguém, algo comum, com a capacidade de trocar ou discutir ideias, de dialogar, de conversar, tendo em vista um bom entendimento entre pessoas. Portanto, a comunicação trata-se tanto de um processo comunicacional, quanto como função de um processo administrativo.

Percebe-se de tal modo que, a comunicação vem alcançando cada vez mais dimensões complexas na organização, assumindo funções essenciais, para que a mesma tenha um bom desenvolvimento, tornando assim uma ferramenta indispensável para o seu sucesso no mercado. 


\subsubsection{A IMPORTÂNCIA DA COMUNICAÇÃO PARA AS ORGANIZAÇÕES}

A comunicação é uma ferramenta de poder nas gestões empresariais, pois ela favorece o desenvolvimento e o equilíbrio das organizações. Porém, nem sempre é valorizada ou reconhecida com a vital importância necessária para o seu desenvolvimento e sobrevivência. Por isso, deve ser esboçada de forma estratégica para alavancar o crescimento organizacional, assim como auxiliar os colaboradores na absorção de resultados positivos.

Segundo Lacombe (2011), é notória a importância da comunicação para o administrador no seu dia a dia. Pois para lidar com pessoas, é fundamental ter uma boa comunicação, para que os resultados sejam alcançados eficientemente. Dessa forma, a comunicação deve fazer parte da identidade da organização, de suas metas e objetivos para representar da melhor forma, sua imagem no mercado.

Chiavenato (2014, p.203) declara que "A comunicação é fundamental para o funcionamento coeso, integrado e consistente de qualquer organização". Sendo assim, torna-se um dos motivos principais para permitir uma boa comunicação, já que tem influência diretamente no processo de tomada de decisões da corporação.

O sucesso de uma organização, entre outras variáveis, vai depender diretamente da comunicação entre os gestores e sua equipe. As atitudes se revelam tanto nos conteúdos quanto nos meios e formas de expressão. Nas organizações a comunicação toma várias direções de acordo com os objetivos que se deseja alcançar, estes objetivos é que vão determinar quais ferramentas serão utilizadas. (CAVALCANTE, 2008, p.7)

Uma organização, depende muito do envolvimento dos seus gestores e colaboradores para ser eficaz. Pois a partir do momento em que há uma comunicação mais perfeita, passarão a conhecer melhor a empresa onde trabalham, passando a saber como desempenhar melhor sua função, proporcionando êxito para a organização, assim também como seu crescimento pessoal. 
Segundo Tomasi e Medeiros (2007), a comunicação é vista hoje como função estratégica da empresa, tendo por objetivo mudar positivamente ou negativamente a imagem da organização junto a seus consumidores e colaboradores, pois é essa a ferramenta principal de relacionamento estabelecida entre a empresa e os diversos públicos da organização.

Desse modo, nota-se que é extremamente relevante para os gestores, assim como a todos os colaboradores. Portanto, a organização precisa propiciar um ambiente favorável para o desempenho, inovação e realização profissional desses indivíduos. Para isso, é necessário remover todas as barreiras que impedem a transmissão correta da informação.

\subsubsection{FUNÇÕES DA COMUNICAÇÃO}

A comunicação é a base de qualquer relacionamento, estando presente sob todos os aspectos no cotidiano das pessoas, dos grupos e das organizações. Ela molda o comportamento dos mesmos, levando em consideração fatos importantes como a estrutura, a hierarquia, a cultura, o clima, as estratégias, entre outros. Sob esta perspectiva, a comunicação passa a ser vista como, o universo das relações que compõem o todo da organização e que, ao mesmo tempo, são influenciadas por essas situações.

A comunicação apresenta, quatro funções básicas em uma organização, grupo ou pessoa, que são: controle, motivação, expressão emocional e informação.

1. Controle: a comunicação apresenta um forte componente de controle no comportamento da organização, dos grupos e das pessoas. Quando as pessoas seguem normas e procedimentos de trabalho ou quando comunicam qualquer problema de trabalho ao seu superior imediato, elas estão fazendo com que a comunicação tenha uma unção de controle. A hierarquia e as orientações formais precisam ser seguidas e a comunicação serve para verificar se realmente isso está acontecendo. $[\ldots]$

2. Motivação: a comunicação promove a motivação ao estabelecer o que uma pessoa deve fazer, avaliar seu desempenho e orientar sobre metas ou resultados a alcançar. A definição de objetivos, a retroação quanto ao 
progresso alcançado e o reforço do comportamento desejável estimulam a motivação e requerem comunicação.

3. Expressão emocional: a comunicação dentro de um grupo constitui uma maneira pela qual as pessoas expressam seus sentimentos de satisfação ou insatisfação. A comunicação é quase sempre um meio de expressão emocional de sentimentos e de satisfação de certas necessidades sociais.

4. Informação: a comunicação funciona como facilitadora da tomada de decisões ao proporcionar informações que pessoas e grupos requerem para tomar decisões, transmitindo dados que identificam e avaliam alternativas de cursos de ação. (CHIAVENATO, 2014, p.206-207)

De acordo com a citação do autor, as quatro funções citadas acima, são de grande importância no cotidiano das organizações, pois, para alcançar o sucesso desejado, os gestores precisam ter controle sobre a equipe, incentivá-la ao esforço, dar oportunidade para que as pessoas expressem suas ideias, tornando-se mais criativas e inovadoras e, criando assim, um ambiente propício e dinâmico. Para tal, é de suma importância oferecer meios e criar condições para que as atividades sejam executadas com clareza e transparência na organização.

\subsubsection{PROCESSO DA COMUNICAÇÃO}

A comunicação consiste em um processo pelo qual se transmite uma informação, na tentativa de criar um entendimento compartilhado. Na organização, qualquer ação começa com a comunicação, por isso, torna-se indispensável o seu processo, pois a informação é codificada e transmitida por um emissor a um receptor através de um canal. A falha em um processo de comunicação pode causar incômodo entre os gestores e colaboradores de uma corporação. Pois um processo comunicativo ineficaz, além de gerar um clima desagradável no ambiente organizacional, pode trazer vários danos para a empresa, tornando-se difícil de recuperá-lo.

As organizações, como mais um cenário do desenrolar dos papéis do homem, oferecem inúmeras possibilidades de comunicação. Ao mesmo tempo, para sua sobrevivência e aprimoramento, dependem de processos de comunicação cada vez mais claros, fidedignos e apropriados. (CASADO, 2002, p.271) 
Percebe-se que na comunicação interna, quanto mais ligados estiverem as partes maior será sua dedicação, motivação e seu envolvimento, no qual resultará estímulos para que suas atividades sejam executadas com eficiência, consequentemente aumentando a produtividade.

Segundo Chiavenato (2009), uma comunicação envolve no mínimo duas pessoas, a que envia e a que recebe a mensagem. É importante ressaltar que, uma pessoa sozinha não se comunica, para o ato ser completo, ela necessita sempre de outra, que será receptora da mensagem enviada. Sendo assim considerada, como um ponto vital que liga as pessoas, compartilhando ideias, sentimentos, técnicas e informações.

De acordo com Lacombe (2011), a comunicação é uma mensagem que na maioria dos casos envolve conteúdos intelectuais e emocionais. Compreendendo assim como um fluxo de informações que ocorre em duas direções, envolvendo um emissor e um receptor, onde este recebe a informação e responde a ela de uma forma documental, visual ou audível.

Para Tomasi e Medeiros (2007), a percepção do indivíduo é um fator relevante no processo de comunicação, pois cada um têm uma forma própria de perceber a realidade. E para que uma estratégia de comunicação adquira seu destino, necessitase pelo menos ter uma ideia, de como o destinatário receberá, ou seja, o que ele absorverá da mensagem que foi lhe passada.

A figura abaixo demostra como acontece o processo da comunicação: 
Figura 01: Processo da Comunicação

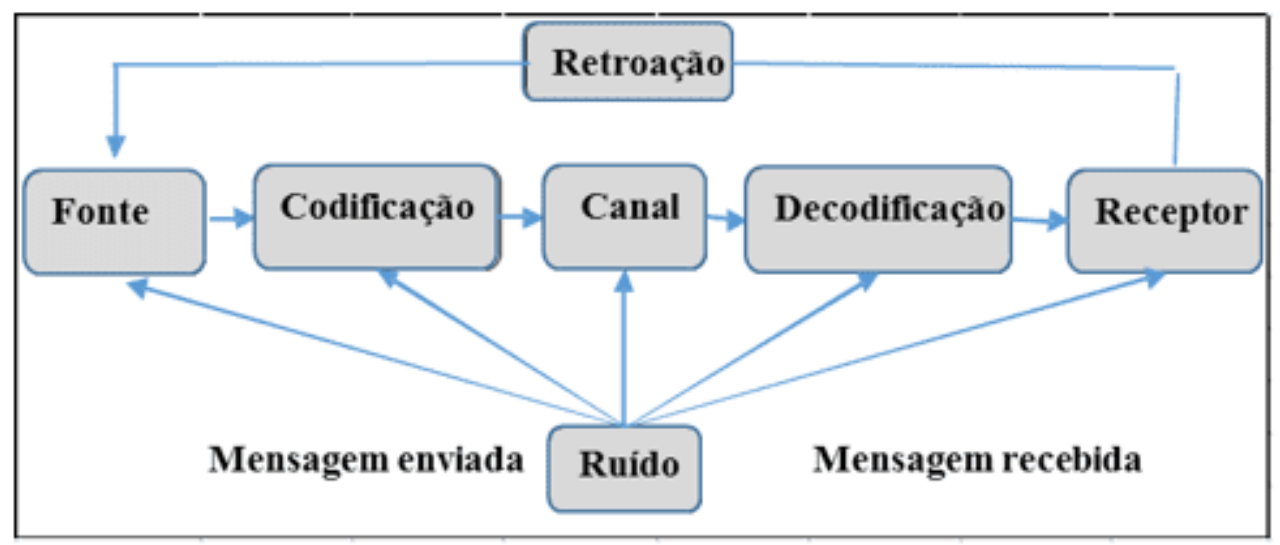

Fonte: Adaptado pelas autoras. Chiavenato (2014, p.208)

O processo de comunicação é complexo, pois o emissor ao enviar uma mensagem, o receptor poderá receber de forma desigual. Por isso, a comunicação nas organizações depende da qualidade da comunicação pessoal. Se as pessoas de uma organização se comunicam eficazmente, os processos tendem a ser eficazes. Portanto, para que uma organização tenha uma comunicação que favoreça suas metas e objetivos, é necessário usar métodos diferenciados e inovadores, recursos técnicos e métodos onde os ruídos, elementos que interferem no processo, possam ser eliminados, para que a mensagem possa fluir melhor, possibilitando crescimento individual e organizacional.

\subsubsection{COMUNICAÇÃO ORGANIZACIONAL}

As pessoas não podem viver isoladas, elas estão constantemente em contato umas com as outras, em um ambiente organizacional não é diferente. Essa é a forma mais comum de relacionamento e interação no cotidiano das pessoas, seja no trabalho ou no meio em que vivem.

Nos dias atuais, as organizações são desafiadas a mostrar uma comunicação ainda mais sólida, particularizada e interativa, tendo em vista as dinâmicas de seus diferentes stakeholders, ou seja, os proprietários, funcionários, gestores, gerentes, 
fornecedores, concorrentes, clientes e sociedade em geral, que estejam relacionadas com qualquer ação desenvolvida na empresa.

A comunicação é utilizada nas organizações com o intuito de motivar ou influenciar o comportamento dos colaboradores, tornando-se eficaz na medida que proporciona um bom relacionamento entre eles, melhorando o funcionamento da organização, favorecendo um clima organizacional harmonioso e dinâmico, que venha favorecer, em geral, a todos os interessados.

Chiavenato (2014, p.216) afirma que, "[...] A comunicação organizacional constitui o processo pelo qual a informação se movimenta, sendo intercambiada pelas pessoas dentro de uma organização. " Nota-se que, a comunicação organizacional é uma ferramenta essencial para estabelecer o diálogo entre as organizações e o seu público, que vem mudando a forma de pensar e agir das empresas, e que atualmente, exibem características de aprimoramento mais acertadas.

Comunicação organizacional, como objeto de pesquisa, é a disciplina que estuda como se processa o fenômeno comunicacional dentro das organizações no âmbito da sociedade global. Ela analisa o sistema, o funcionamento e o processo de comunicação entre a organização e seus diversos públicos. (KUNSCH, 2003, p. 149).

Assim, de acordo com a citação acima, entende-se que, a comunicação é uma ferramenta estratégica fundamental para que as organizações busquem crescimento e desenvolvimento, pois tem um papel fundamental na troca de informações entre seu público estratégico e sociedade em geral. Dessa forma, a comunicação organizacional torna-se responsável pela construção de uma relação harmoniosa com seu público interno e externo, tendo como principal objetivo, otimizar tais relacionamentos buscando uma sintonia com todos.

\subsubsection{COMUNICAÇÃO EXTERNA}

Comunicação externa compreende toda informação que esteja relacionada com as atividades desenvolvidas na organização, conectando-a com o meio ambiente externo. Essas ações são promovidas com a intenção de captar e manter seus 
clientes, através da divulgação de sua imagem institucional, da produção de conteúdo nos meios eletrônicos e no atendimento ao público que se encontra fora da organização. Considera-se, portanto que, a comunicação externa é determinante para o sucesso da organização. Independente do seu porte, ela tem a necessidade defender, preservar e fortalecer a imagem da organização, destacando principalmente sua missão, visão, valores e princípios, presente na organização.

Para Torquato (2002), a comunicação externa é responsável pelo posicionamento e pela imagem da organização na sociedade, tendo como foco principal a opinião do público externo. Tornando-se passível a constantes mudanças, diante das circunstâncias, ao acompanhar as tendências de opinião pública constituindo assim, como dever prioritário do comunicador.

Tomasi e Medeiros (2007. p.81), relata:

A comunicação externa deve pautar-se por valores que a sociedade exige nos dias de hoje, como verdade, qualidade, confiabilidade, clareza, equilíbrio, rapidez, cordialidade, respeito, responsabilidade social.

Os objetivos da comunicação externa são: divulgar a missão da empresa, assegurando identidade que possa conferir à empresa respeito e reconhecimento por parte do mercado, e criar atitude favorável em relação ao produto ou serviço da empresa.

Entende-se, que a comunicação externa deve ser utilizada pelas organizações com a finalidade de desenvolver e promover sua imagem no mercado junto ao seu públicoalvo, principalmente seu consumidor, passando uma imagem positiva à sociedade em geral.

A comunicação externa deve cumprir as funções de manter os diversos públicos-alvo, informado suficientemente sobre a organização e suas operações, agregando valor à marca e à imagem da organização, defendendo-a em situações emergenciais e disponibilizando recursos de comunicação para a empresa em geral. $\mathrm{O}$ autor considera como público alvo os clientes, a comunidade, público interno (colaboradores em geral), acionistas, financiadores, investidores, órgãos públicos, imprensa e formadores de opinião em geral. (CHIAVENATO, 2004) 
Os objetivos da comunicação externa são divulgar a missão da empresa, assegurando identidade que possa conferir à empresa respeito e reconhecimento por parte do mercado, criando uma atitude favorável em relação ao produto ou serviço da empresa.

Através do raciocínio acima, pode-se perceber que, a comunicação externa cuida da imagem que a organização transmite para seus stakeholders. Ela constrói uma ponte entre as organizações, consumidores e potenciais clientes. Sendo necessário desenvolver estratégias para se destacar no mercado, divulgar sua marca, conquistar seus clientes e sustentar sua identidade na mente dos consumidores. Sendo assim, é preciso avaliar o ambiente de mercado e identificar os canais e processos de comunicação ideais para o público-alvo.

\subsubsection{COMUNICAÇÃO INTERNA}

Atualmente, no mundo competitivo e inovador, a comunicação interna soma valores para as organizações, pois a própria torna-se incapaz de gerar resultado positivos se seus colaboradores/parceiros, não estiverem cientes de suas tarefas, assumindo o compromisso de exercer a missão e ampliar a visão da organização, determinando assim, sucesso da mesma.

Angeloni (2010, p.71) esclarece que, "A comunicação interna deve não apenas suprir o público interno com informações relativas aos negócios em si, mas também com informações referentes ao que se passa no ambiente externo". Além disso, atua como fator humano nos relacionamentos organizacionais, consolidando a imagem da empresa junto aos stakeholders, tornando-se inerente nos resultados dos negócios. Abrangendo assim, uma comunicação interna adequada é a condição básica para uma comunicação externa de qualidade.

Hoje, podemos definir a comunicação interna como o conjunto de ações que a organização coordena com o objetivo de ouvir, informar, mobilizar, educar e manter coesão interna em torno de valores que precisam ser reconhecidos e compartilhados por todos e que podem contribuir para a construção de boa imagem pública. (CURVELLO, 2012, p.22) 
Baseando-se na visão do autor acima, o objetivo básico da comunicação interna é propiciar a troca de informações dentro da organização, ouvindo e compreendendo seus colaboradores, transformando esses dados em conhecimentos. Sendo assim, a comunicação interna, destina-se a facilitar e viabilizar a interação entre a organização e seus colaboradores, mantendo a harmonia no ambiente interno, refletindo uma imagem positiva para o público externo. Tecnicamente, uma boa comunicação interna, é um sistema que visa facilitar o fluxo de informações úteis entre todos os colaboradores de uma empresa.

\subsubsection{FLUXOS DA COMUNICAÇÃO INTERNA}

Nas organizações as informações percorrem caminhos distintos, que variam de acordo com o público que pretende atingir. O veículo de informação a ser utilizado, deve-se alcançar todos os públicos, mas a linguagem usada no nível operacional não será a mesma usada no nível estratégico ou no tático. Pois, uma organização possui colaboradores com níveis de escolaridade diferentes, que atuam em diversos setores, desde o nível operacional até o estratégico. A figura abaixo mostra o movimento que a comunicação percorre na organização:

Figura 02: Fluxos da comunicação interna

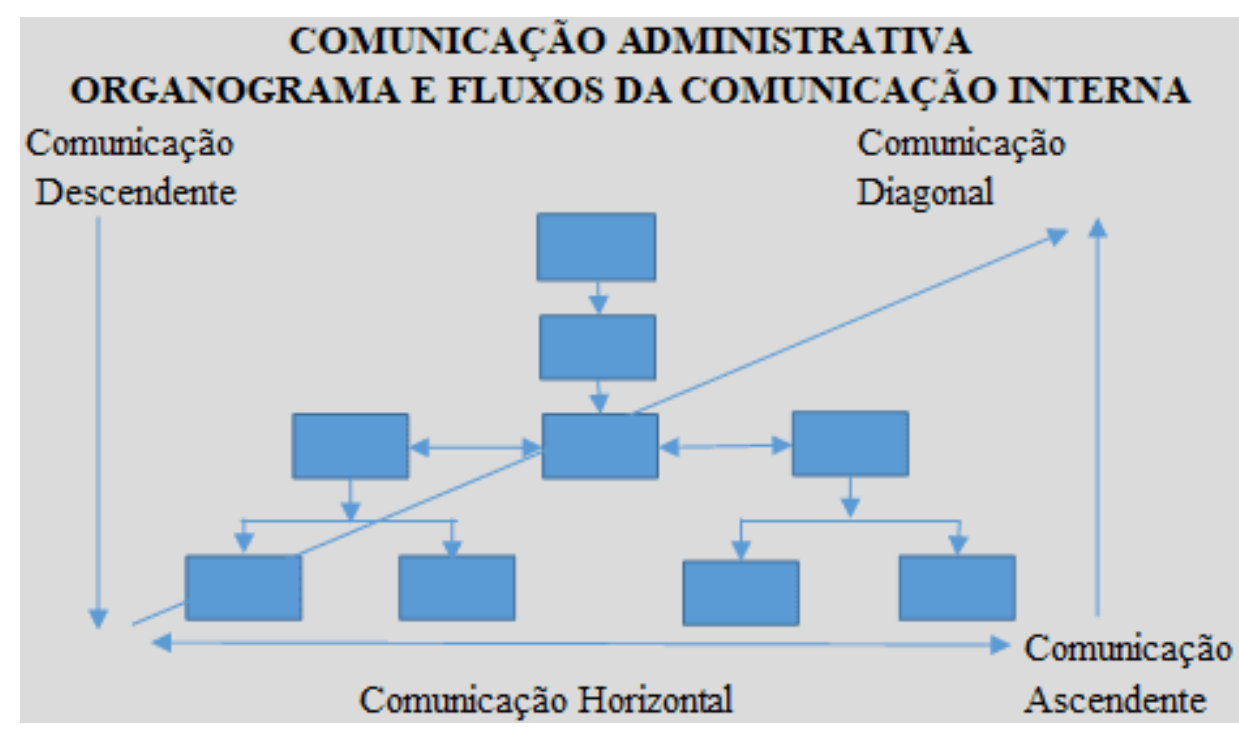

Fonte: Slideplayer. Adaptação reproduzida pelas autoras (2017). 
Chiavenato (2014, p.216) informa que, " [...]. Existem três tipos de canais formais: as comunicações descendentes, as ascendentes e as horizontais. " Os verticais são dos diretores para os subordinados ou vice-versa, classificando-se de cima para baixo (descendente) ou de baixo para cima (ascendente). Os horizontais são entre os departamentos.

Segundo Montana e Charnov (2003), a composição da comunicação na organização inclui um canal a mais, que é a comunicação diagonal. Esse fluxo percorre todas as direções, sem distinção de níveis hierárquicos, acontecendo geralmente nas organizações mais flexíveis.

É notório que, nas organizações se convive com diversos fluxos de comunicações, determinando a forma de se relacionar com os superiores hierarquicamente, com seus pares, com seus subordinados, seus clientes internos e externos. Para que a comunicação interna atue mais fortemente nas organizações é necessário que se estenda em todas as direções, permitindo que as informações, opiniões e conhecimentos circulem em todos os sentidos, garantindo assim um desempenho mais coordenado, evitando as falhas e os ruídos do processo.

\subsubsection{COMUNICAÇÃO VERTICAL E DESCENDENTE}

A comunicação descendente, está relacionada com informações enviadas da alta e média administração aos empregados como um todo, considerada também como vertical, ou seja, de cima para baixo, proporcionando orientação para os níveis mais baixos da organização.

Chiavenato (2014, p.217) destaca que, a comunicação descendente:

[...]. É o tipo de comunicação vertical para criar empatia e gerar um clima de trabalho conjunto para a busca de soluções de problemas na organização. $O$ administrador pode comunicar para baixo da hierarquia por meio de conversas, reuniões, mensagens em publicações da organização, correio eletrônico, telefonemas, memorandos, vídeos, seminários, cartas e manuais de políticas e procedimentos. [..] 
Nesse sentido, avalia-se que, a comunicação vertical descendente, são as ordens para implantação de programas, políticas e métodos de trabalho, vindo dos níveis mais elevados hierarquicamente para os mais baixos. Verifica-se que, a função básica da comunicação de cima para baixo é, categoricamente dar suporte a seus subordinados, passando as informações dos artifícios e dos objetivos da organização.

\subsubsection{COMUNICAÇÃO VERTICAL ASCENDENTE}

A comunicação ascendente, tem seu fluxo ao contrário da descendente. Direciona-se dos níveis mais baixos aos mais altos escalões da organização, sendo utilizada para fornecer o feedback aos gestores, informando-os a respeito do progresso das metas, problemas ocorridos, a satisfação dos colaboradores e também para obter ideias sobre o que pode ser melhorado.

Esse fluxo permite que se conheça como as tarefas são desenvolvidas, suas realizações e problemas ocorridos com os colaboradores. A comunicação de baixo para cima também propicia o surgimento de novas ideias e facilita a comunicação descendente.

O fluxo ascendente se caracteriza pelas informações, geralmente sugestões, críticas e apelos, oriundas dos funcionários e dirigidas à direção. As seções de cartas, as colaborações, existentes em quase todos os jornais de empresa e particularmente naquele por nós analisado, caracterizam esse fluxo. (CURVELLO 2012, p.23)

Com base na citação do autor acima, a comunicação ascendente é o meio que os colaboradores têm para reclamar de algo que está afetando seu desempenho na organização. Nota-se que, o percurso da comunicação nesse fluxo inicia-se, por exemplo, no setor produtivo em direção aos supervisores e gerentes. Em organizações mais tradicionais, esse é um tipo de comunicação mais difícil de acontecer devido a sua estrutura bastante hierarquizada.

Esse fluxo relaciona-se às observações das informações, produzidas através dos relatórios, pesquisas e sugestões dos colaboradores. Quando bem utilizada, esse modelo de comunicação é uma forma de crescimento para a organização e para seu 
capital humano. Pois, quando a organização ouve seus colaboradores, abrindo um caminho específico para receber suas opiniões e contribuições, ela cria um ambiente ameno, onde todos podem se ajudar e melhorar os aspectos negativos e a impulsionar aqueles considerados positivos.

\subsubsection{COMUNICAÇÃO HORIZONTAL}

No sentido horizontal, a comunicação ocorre entre as pessoas da mesma linha hierárquica, podendo ser membros da mesma equipe de trabalho ou de outras diferentes. A comunicação horizontal contrai uma especial relevância nas organizações descentralizadas, ou seja, ela comprime os níveis hierárquicos mais baixos a tomarem decisões.

Através da comunicação horizontal é possível organizar as atividades, assim como solucionar devidos problemas, sem necessitar direcionar a comunicação a um plano de hierarquia superior. Esse fluxo propicia o compartilhamento de informações e conhecimentos, além de integralizar os membros de outro grupo.

Conforme Montana e Charnov (2003), a comunicação horizontal ou lateral ocorre entre funcionários do mesmo nível hierárquico, tendo a função de movimentar o cotidiano das organizações através da comunicação entre os setores, situando-se quase sempre, no campo informal. Percebe-se que, essa comunicação ocorre entre as unidades de trabalho do mesmo nível e visa a colaboração, o compartilhamento de informações, de ideias entre os funcionários.

Observa-se que, esse tipo de fluxo da comunicação serve para ajustar o tempo e facilitar a coordenação, entre os gestores ou colaboradores de uma mesma categoria. Porém, pode causar conflitos disfuncionais quando os canais formais de um grupo são infringidos ou excedidos para atingir os resultados ou tomar decisões sem conhecimento de seus superiores. 


\subsubsection{COMUNICAÇÃO DIAGONAL}

A comunicação diagonal, também conhecida como transversal, acontece com a troca de mensagens entre um superior e um subordinado de outro departamento ou de outra área. Desse modo, permite-se o funcionamento dos processos interdepartamentais, envolvendo diferentes níveis hierárquicos simultaneamente.

Para Montana e Charnov (2003), comunicação diagonal ocorre entre dois níveis hierárquicos. Mesmo que essa forma de comunicação não adotem o organograma habitual das organizações, ela é essencial para o funcionamento da organização contemporânea.

Segundo Tomasi e Medeiros (2007), o fluxo diagonal abrange as comunicações formadas entre um gerente de um departamento e um colaborador de outro. Geralmente utilizado pelas organizações abertas, ou seja, menos burocráticas. Apresentando pontos positivos como a rapidez e a transparência das informações dentro das organizações.

Avalia-se que, a comunicação interna depende da qualidade da comunicação desde o nível estratégico até o operacional de uma organização. Geralmente as organizações flexíveis procuram criar condições para que as pessoas passem a interagir e intervir em diferentes áreas.

\section{METODOLOGIA}

O referido estudo foi realizado na cidade de Belém, capital do estado do Pará, com 144 municípios, sendo atualmente a cidade mais populosa do Estado. Possui uma população estimada em 1.446.042, segundo dados do Instituto Brasileiro de Geografia e Estatística - IBGE. Sua densidade demográfica é de 6,7 hab./km² (IBGE, 2010) e a renda per capta de $\mathrm{R} \$ 672,00$. (IBGE, 2015). Conforme identifica-se a localização geográfica no mapa abaixo: 
Figura 03: Localização geográfica da cidade de Belém-PA

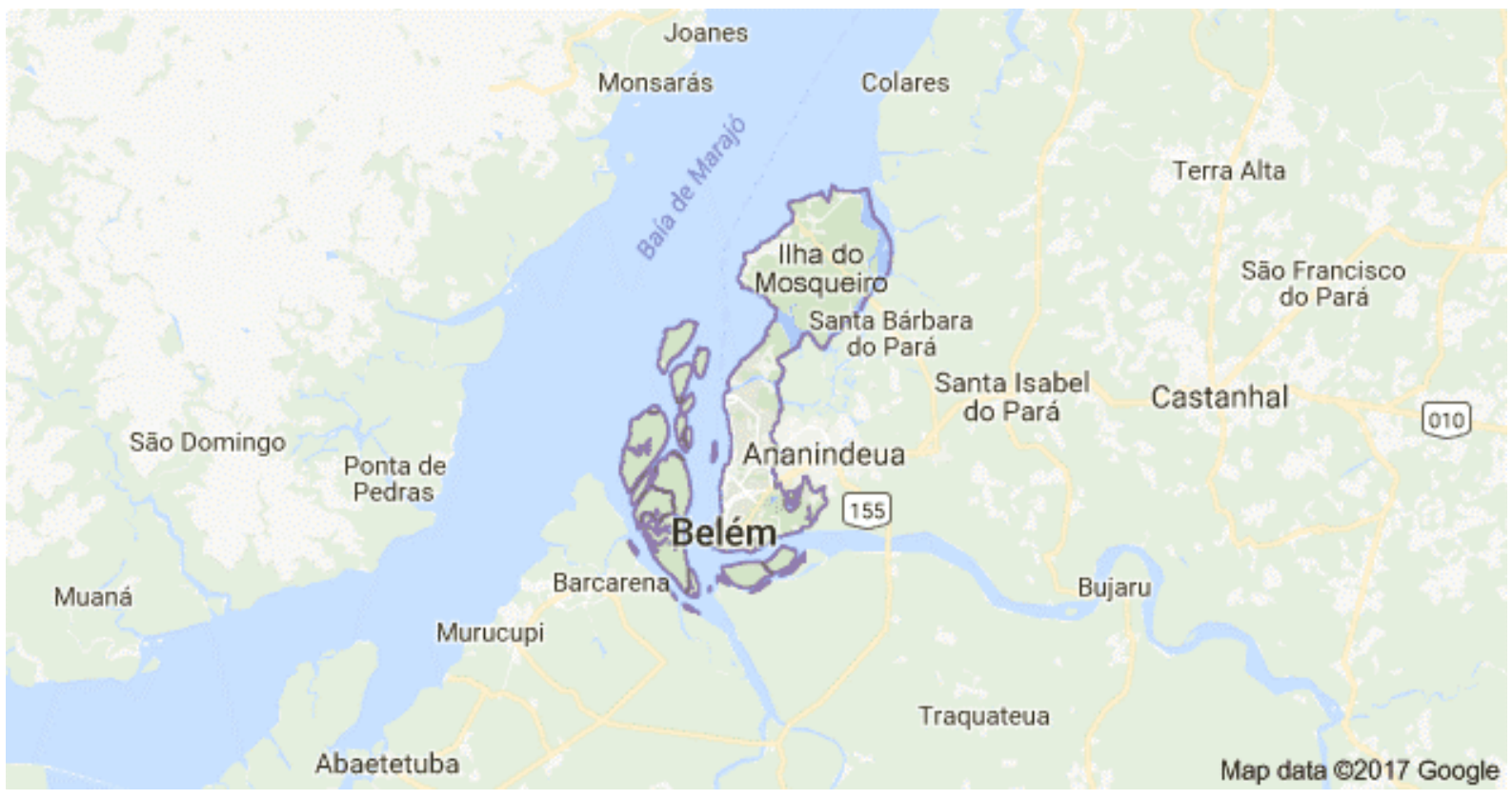

Fonte: Site Belémtur (2017)

A referida empresa estudada possui atualmente um quadro com doze funcionários. Situada em uma área comercial privilegiada, onde existem vários seguimentos mercantis instalados. Atualmente é constituída de 01 gestor administrativo e 12 funcionários que compõem o seu quadro ativo.

A coleta de dados foi realizada por meio de entrevista sendo possível coletar os dados, torna-se necessário a classificação e estruturação dos mesmos, transformando-os assim em conclusões pertinentes e de credibilidade. Este procedimento ajuda o pesquisador, impedindo que os trabalhos sejam feitos desnecessários. Além de possibilitar a previsão dos gastos necessários para a realização da pesquisa. Essa etapa então é conhecida como análise de dados. Conforme a seguir o modelo de questionário aplicado: 
Tabela 01: questionário de pesquisa

ROTEIRO DE ENTREVISTA

1) Como define-se a comunicação interna para a organização?

2) Qual a importância da comunicação interna para as organizações?

3) A organização considera a comunicação interna como uma ferramenta estratégica utilizada para conseguir destacar-se no mercado competitivo atual?

4) Qual a relação da comunicação interna com a cultura organizacional da empresa?

5) Quais os meios de comunicação interna que a empresa adota para se comunicar com seus colaboradores?

6) A empresa costuma receber um feedback dos funcionários? Esse feedback geralmente são reclamações e solicitações?

7) De que forma a empresa utiliza a comunicação interna para obter um clima organizacional harmonioso entre os colaboradores e gestores?

8) Existe uma integração interdepartamental na empresa? Como essa integração pode ser visualizada dentro da empresa? Essa integração é atribuída aos tipos de ferramentas de comunicação interna existentes na empresa?

9) Até que ponto o processo de comunicação interna da empresa se encontra condizente com o planejamento estratégico requerido para o alcance de objetivos e metas organizacionais?

10) Como é a relação da comunicação interna entre os superiores e colaboradores e vice-versa?

11) Como ocorre o processo de comunicação na organização?

12) As formas de comunicação utilizadas na empresa são suficientes para o processo de comunicação?

13) Quais as principais barreiras encontradas na comunicação dentro da empresa?

14) A comunicação interna sofre com frequência interferências de ruídos?

15) Há algo que poderia ser melhorado na comunicação interna da organização? O que?

Fonte: Elaborado pelos autores (2017).

Ressalta-se, portanto que, a análise dos dados coletados traz uma consistência para qualquer pesquisa. Contudo, isso exige um trabalho bastante denso por parte do pesquisador, deixando claro a interpretação e análise da investigação do objeto específico da pesquisa.

\section{ANÁLISE DE DADOS}

Sobre a comunicação interna na empresa de Importados, loja BR-316, obtendo a seguinte resposta: "A comunicação interna é próxima e direta, por meio de diálogos entre gestores e colaboradores, para que haja maior eficiência e eficácia no trabalho. $"$

De acordo com Curvello (2012), a comunicação interna define-se como o conjunto de ações que a organização coordena com o objetivo de ouvir, informar, mobilizar, educar e manter uma conexão interna que contribua para a construção de uma boa imagem pública da empresa. 
Portanto, entendeu-se claramente que, a comunicação interna é um entrosamento entre a empresa e os colaboradores, onde as informações têm possibilidades de fluírem entre ambos de forma dinâmica. Logo, a comunicação é um elemento inseparável na relação entre gestores e colaboradores, pois é através da mesma, que as informações circulam, compartilhando-as assim, uns com os outros.

Com a representante da empresa, se perguntou sobre a importância da comunicação interna para as organizações. De acordo com o relato da mesma, constatou-se que a comunicação interna é de suma importância para a organização, pois deixa os colaboradores mais motivados, além de solucionar possíveis problemas, auxiliando na tomada de decisão, além das atividades coletivas fluírem melhor.

Argumentou-se com a participante se a organização considera a comunicação interna como uma ferramenta estratégica, para destacar-se no atual mercado competitivo atual, a gestora da empresa relatou que: "Sim. Pois, a internet facilita a formulação de estratégias de comunicação, com a finalidade de expandir os negócios da organização."

Para Tomasi e Medeiros (2007), a comunicação é vista como uma ferramenta estratégica da empresa, podendo mudar positivamente ou negativamente a imagem da entidade, junto com os seus stakeholders, pois ela é o principal artifício no relacionamento entre ambos.

Percebe-se, que na organização, a comunicação é uma das ferramentas mais eficazes para sobreviver e prosperar no mercado competitivo atual. Quando se traça uma estratégia, pode-se obter resultados positivos ou negativos para a empresa, pois quando há planejamento eficiente, a organização apresenta mais oportunidades de alcançar êxito nas suas pesquisas, porém quando os resultados são negativos, pode influenciar no clima organizacional da mesma, causando desarmonia entre seu público.

Verificou-se como a gestora, qual a relação da comunicação interna com a cultura organizacional da empresa. Entendeu-se através do seu relato que, a comunicação 
da empresa encontra-se interligada com a cultura organizacional, apresentando uma boa relação, com proximidade entre diretoria, gerência e colaboradores.

Curvello (2012) informa que, através da ótica da comunicação pode-se conhecer e compreender a cultura organizacional, além de captar a conexão das relações internas, suas contradições, suas mediações, para melhor compreender os estágios administrativos, os sucessos e fracassos organizacionais e as facilidades ou dificuldades impostas às mudanças.

Para que o processo de comunicação organizacional ocorra eficientemente, mantendo informados todos os públicos da empresa, é necessário conhecer a cultura da organização, sua história, funções, objetivos, interesses, realidade e as relações com os envolvidos. A comunicação tem relação direta com a cultura da entidade desenvolvida através de uma maior efetividade e credibilidade junto ao público interno, sendo também, um fator estratégico nos processos de mudança da organização.

Perguntou-se quais os meios de comunicação interna que a empresa adota com seus colaboradores, sendo informado pela gestora que: "Os meios de comunicação interna utilizados na empresa de Importados, são o telefone, intranet, internet (whatsapp e email), quadro de avisos e reuniões". Apesar dos outros meios de comunicação existentes, o contato direto, ainda é a melhor forma de transmitir as informações no âmbito organizacional.

Para Lacombe (2011), o contato direto é um dos meios mais antigos e o principal instrumento de comunicação, possuindo sinais que são insubstituíveis, vistos através de gestos, olhares, sorrisos, capazes de transmitir as informações que não perceptíveis.

Os meios de comunicação são instrumentos que auxiliam a organização para transmitir informações, promovendo uma sinergia entre as partes envolvidas, para alcançar os resultados almejados, podendo ser moldadas de acordo com a necessidade das mesmas. A escolha do canal de informação a ser utilizado depende, 
não somente, do que se vai transmitir como também do resultado a ser alcançado e do feedback desejado.

Indagou-se de que forma a empresa utiliza a comunicação interna para obter um clima organizacional harmonioso entre os colaboradores e gestores, a entrevistada replicou que: "Através de reuniões em grupos e contato direto."

De acordo com a citação já mencionada de Lacombe (2011), o clima organizacional reflete o grau de satisfação dos colaboradores com a organização. Está associado a motivação, a lealdade, a identificação com a empresa, melhor relacionamento entre as pessoas e a interação da equipe. Sendo assim, é objetivo do nível estratégico manter um clima harmonioso, para satisfazer a necessidade de seus clientes, por isso torna-se imprescindível manter a harmonia no ambiente de trabalho mesmo que nem sempre sejam alcançados os objetivos propostos, é uma meta da empresa para que através de um ambiente saudável, seja possível realizar um trabalho mais eficiente e eficaz e se manter no mercado que se torna cada vez mais competitivo.

De acordo com os autores vistos na teoria, Montana e Charnov (2003), a comunicação interdepartamental, ocorre através da comunicação horizontal, ou seja, entre colaboradores do mesmo nível hierárquico, com a função de movimentar e compartilhar as informações do cotidiano das empresas.

Verificou-se qual a opinião da entrevistada sobre até que ponto o processo de comunicação interna da empresa se encontra condizente com o planejamento estratégico requerido para o alcance das finalidades almejadas.

Em relação a este argumento, foi possível analisar que o planejamento estratégico é fundamental para o alcance dos objetivos e metas da empresa, sendo de extrema importância uma comunicação harmônica entre os stakeholders, apesar de ocorrer falhas no processo, tem sido alcançado com êxito.

Segundo Maximiano (2010), planejar estratégias na organização, significa traçar uma ação, para certificar-se de como seus objetivos serão desempenhados, para que suas metas sejam alcançadas. 
Foi identificado como é a relação da comunicação interna entre os superiores e colaboradores e vice-versa. A mesma relatou que: "A comunicação na empresa é feita de forma direta e de muito fácil acesso. "

Conforme descreve o autor Chiavenato (2014), a comunicação vertical descendente, ou seja, de cima para baixo, foi criada para gerar uma afinidade e um clima de trabalho conjunto, buscando solucionar problemas na organização. Podendo assim, o gestor se comunicar com seus subordinados, principalmente através de conversas e reuniões.

Sobre o fluxo vertical ascendente, pode-se ratificar essa análise com Curvello (2012), relata que acontece de baixo para cima, caracterizando-se pelas informações, sugestões, críticas ou apelo dos colaboradores levadas aos gestores.

Foi questionado como ocorre o processo de comunicação na organização. Sobre este resultado pôde constatar que a mensagem é emitida pelo nível estratégico, codificada de forma escrita ou verbal e transmitida pelos meios existentes na organização, que são os chamados canais. A mensagem é recebida pelo nível tático ou operacional, retornado ao emissor, confirmando o recebimento e a sua forma de compreensão.

Na visão de Tomasi e Medeiros (2007), a capacidade de entendimento do indivíduo é um fator relevante no processo de comunicação, já que cada um têm uma forma adequada de perceber a realidade. Assim, para uma estratégia de comunicação adquirir seu destino, necessita saber pelo menos como o destinatário receberá a mensagem que Ihe foi passada. Nesse aspecto, para haver comunicação entre emissor e receptor é necessário a existência de um canal de comunicação, para que a mensagem seja bem elaborada, onde ambos estejam integrados sempre em um mesmo contexto.

Foi abordado quais as formas de comunicação utilizadas na empresa são suficientes para o processo de comunicação. A entrevistada respondeu que considera suficientes, mas segundo o relato da mesma, há interferências no processo de 
comunicação, ocasionado pelo mal funcionamento da rede de internet atualmente utilizada pela empresa, dificultando a transmissão das informações em tempo hábil.

Lacombe (2011) faz evidência sobre os meios eletrônicos nas empresas, onde atualmente é a forma mais usual e importante de comunicação e a perspectiva é de aumento, com o avanço da tecnologia.

Entende-se que, o ato de comunicar envolve não somente as palavras expressas verbalmente, mas também, outros métodos como a escrita, símbolos ou códigos, tecnologia, além das diversas maneiras de manifestar as emoções e os sentimento das pessoas. Mas, atualmente o fácil acesso a novas informações, constituem uma realidade na vida das pessoas. Hoje a internet disponibiliza ferramentas que auxilia no dinamismo das organizações modernas, tornando o processo de comunicação cada vez mais rápido, capazes de alterar profundamente o contexto das relações de trabalho e o comportamento organizações contemporâneas.

Existem diversas barreiras que impedem uma comunicação eficaz, sendo necessário atuar em cada uma delas para garantir que as informações cheguem ao destino correto, no tempo adequado e com a clareza necessária. Dessa forma, pode-se descrever que, as falhas na comunicação causam prejuízos e atrasos das atividades nas empresas.

Foi solicitado à informante, que explicasse se a comunicação interna sofre com frequência interferências de ruídos. A esta indagação, a mesma ressaltou de acordo com décima terceira pergunta. Respondeu de forma afirmativa, que os ruídos ocorrem devido problemas com a internet, provocados por fatores aleatórios, causados por agentes externos ao sistema operacional da empresa, o qual vem afetando a empresa negativamente, impedindo que a comunicação ocorra de forma eficaz.

Conforme Cavalcante (2008), os ruídos interferem na mensagem, causando distorção da mesma ao transmitir a informação ao receptor. Existem vários tipos de canais utilizados para se transmitir uma mensagem, sendo necessário identificar os mais eficientes e eficazes para alcançar os objetivos desejados pela organização. 
No processo da comunicação, entre emissor e receptor, a mensagem pode encontrar ruídos, distorcendo assim a informação, sendo considerada uma das principais causas dos problemas de comunicação em uma empresa. Quando se trabalha uma comunicação eficiente, erros e retrabalhos, conflitos e desmotivação não fazem parte da rotina da empresa.

Na décima quinta pergunta, argumentou-se com a participante da entrevista, se há algo que pode ser melhorado na comunicação interna da organização. Diante deste questionamento, avaliou-se que, a empresa necessita de uma internet eficaz que atenda às necessidades da empresa. Também a criação de normas de direcionamento para os colaboradores, repassadas aos mesmos desde a contratação.

De acordo com a definição do autor, Silva (2008), a missão organizacional, as estratégias, as metas e a cultura devem ser informada de modo eficaz, para que sejam atingidas e finalizadas com sucesso.

\section{CONSIDERAÇÕES FINAIS}

O estudo realizado apontou a importância da comunicação interna como uma estratégia para o desenvolvimento das organizações. Verificou-se que a comunicação é de grande valor na vida das pessoas, das empresas, da academia e da sociedade em geral, pois é através dela, que os mesmos trocam informações, mantêm relacionamentos, dividem emoções, partilham experiências, compartilham ideias, transformando assim, o ambiente em vivem.

Foi analisado que, para que ocorra de fato a comunicação, é necessário o envolvimento de pelo menos duas pessoas no processo - o emissor que transmite a mensagem, e o receptor que recebe a mensagem e interpreta-a. Compreendeu-se que o processo de comunicação na organização precisa ser claro, objetivo e trabalhado de forma organizada, pois para que a empresa se desenvolva, a produtividade seja alcançada e as decisões administrativas possam ser tomadas corretamente, é preciso que as pessoas envolvidas se comuniquem bem e estejam interligadas no processo. Identificou-se ainda que, sem uma comunicação interna 
eficaz, as empresas não conseguem atingir seus objetivos. Em decorrência disso, a comunicação passou a ser considerada de vital necessidade para as corporações, sua importância é tal, que essa ferramenta vem sendo valorizada e reconhecida como uma estimável vantagem competitiva.

Constatou-se que, existem vários fatores que favorecem o crescimento de uma corporação, porém, a comunicação apresenta-se como uma dessas importantes ferramentas, visto que, o sucesso da mesma e a manutenção de seus funcionários, concentra-se em uma sólida comunicação interna, motivadora de um clima organizacional harmonioso, que pode aumentar a operosidade da corporação, tornando-se um fator determinante para o sucesso ou fracasso da empresa.

É importante também, que a organização identifique as barreiras que possa interferir e distorcer o processo de comunicação empresarial e o andamento das atividades organizacionais; como por exemplo: uma estrutura organizacional com hierarquia rígida, reações emocionais, ausência de feedback, etc. Após a organização fazer esta identificação, é possível realizar melhorias para que a comunicação se torne eficiente e eficaz. Em relação ao feedback, quando se encontra aliado ao contato humano, se torna uma ferramenta chave que proporciona aos gestores uma ligação direta com seus subordinados, para que haja troca e compreensão das informações entre eles. Assim, os objetivos organizacionais poderão ser alcançados, e a equipe de trabalho poderá se tornar mais motivada e comprometida com o crescimento e desenvolvimento da organização e também com a busca pelo sucesso organizacional.

O segundo objetivo se propôs a identificar os meios e processos de comunicação utilizados atualmente na empresa analisada. Foi respondido através da entrevista feita com a gestora da organização, onde a mesma informou que são o telefone, quadro de avisos, reuniões, intranet, internet e redes sociais.

O sucesso da comunicação depende da qualidade da comunicação pessoal, se houver uma comunicação eficaz entre as pessoas da organização, os processos tendem a serem eficazes, promovendo uma melhor qualidade no ambiente de trabalho, aumentando o rendimento dos mesmos, pois quando o colaborador está 
informado, sobre as necessidades da empresa, consegue ter uma visão melhor do andamento do seu desenvolvimento.

Avaliou-se que os ruídos atrapalham o fluxo da comunicação, prejudicando o desenvolvimento do trabalho, trazendo desconforto e interferindo na qualidade das atividades executadas na organização. Recomenda-se avaliar as condições do trabalho desenvolvido, eliminando a existência dos mesmos, através de uma comunicação clara e objetiva, no intuito de melhorar o convívio entre setores e evitar possíveis erros. Pois uma comunicação sem falhas ou ruídos agrega valores a qualquer corporação, favorecendo a todos os envolvidos.

A análise dos dados permitiu responder à questão deste estudo, que abordou o seguinte problema: Como uma comunicação eficaz pode contribuir para que os colaboradores desenvolvam suas atividades em busca do desenvolvimento organizacional? De acordo com as análises da pesquisa, pôde-se avaliar que, uma comunicação de forma eficaz, pode contribuir sim, para o desenvolvimento das organizações, criando estratégias internas, para estimular a integração e motivação dos colaboradores, para que haja um comprometimento com a missão, visão, princípios e valores. Procurando conscientizá-los sobre a relevância de ter uma comunicação eficaz, da sua importância para despenhar suas funções e para o desenvolvimento na empresa. De acordo com o trabalho realizado, conclui-se, portanto, que, o objetivo geral e os específicos, foram alcançados bem como a pergunta problema foi respondida.

\section{REFERÊNCIAS}

ANGELONI, Maria Terezinha. Comunicação nas Organizações da Era do Conhecimento. São Paulo: Editora Atlas, 2010.

Belém Importados - Site Oficial. Informações da empresa. Disponível em:<http://www.belemimportados.com/quemsomos.aspx> Acesso em: 07 de setembro de 2016. 
BOWDITCH, James L.; BUONO, Anthony F. Elementos do comportamento organizacional. São Paulo: Editora Cengage Learning, 2009.

CASADO, Tânia. As Pessoas na Organização. São Paulo: Editora Gente, 2002.

CAVALCANTE, Shirley Maria. Gestão da comunicação organizacional: Conhecendo as ferramentas e suas aplicabilidades. João Pessoa: [s.n], 2008.

CHIAVENATO, Idalberto. Teoria geral da administração. Rio de Janeiro: Campos, 2003.

Administração dos novos tempos. 2.ed. Rio de Janeiro: Elsevier, 2004.

. Administração de recursos humanos: fundamentos básicos. 7.ed. Barueri, SP: Manole, 2009.

- Comportamento organizacional: a dinâmica do sucesso das organizações. 3.ed. Barueri, SP: Manole, 2014.

CRESPO, Antônio Arnot. Estatística fácil. 19.ed. atualizada. São Paulo: Saraiva, 2009

CURVELLO, João José Azevedo. Comunicação interna e cultura organizacional 2. ed. rev. e atual. - Brasília: Casa das Musas, 2012.

FRANÇA, Ana Cristina Limongi. Práticas de Recursos Humanos - PRH: Conceitos, Ferramentas e Procedimentos. 1. ed.- 4 reimp. - São Paulo: Atlas, 2010.

GIL, A. C. Como elaborar projetos de pesquisa. 4. ed. São Paulo: Atlas, 2007. Como elaborar projetos de pesquisa. 5. ed. São Paulo: Atlas, 2010. Métodos e Técnicas de Pesquisa Social. 6 ed. São Paulo: Atlas 2010. 
IBGE- Site Oficial. IBGE Cidades Infográfico Pará Belém. Dados Gerais. Disponível: $<$ http://cidades.ibge.gov.br/painel/painel.php?codmun=150140>. Acesso em 21 de setembro de 2016.

LACOMBE, Francisco J. M. Recursos Humanos: Princípios e tendências. 2.ed. São Paulo: Saraiva, 2011.

. Comportamento Organizacional. São Paulo: Saraiva, 2012.

LACOMBE, F. J. M.; HEILBORN, G. L. J. Administração: princípios e tendências. São Paulo: Saraiva, 2008.

LUPETTI, Marcélia. Gestão estratégica da comunicação mercadológica. São Paulo: Thomson Learning, 2007.

KUNSCH, Margarida M. Krohling. Planejamento de relações públicas na comunicação integrada. 4. ed. São Paulo: Summus, 2003.

MACEDO, Neusa Dias de. Iniciação à Pesquisa Bibliográfica: guia do estudante para a fundamentação do trabalho de pesquisa. 2. ed. São Paulo: Edições Loyola, 1994.

MANESCO, Maíra. Assessora de Imprensa na Race Comunicação. Artigo publicado em 01/08/2013. Disponível em <http://www.racecomunicacao.com.br/blog/aimportancia-da-comunicacao-para-as-empresas/> Acesso em: 28 de agosto de 2016.

MARCONI, Marina de Andrade, LAKATOS, Eva Maria. Metodologia do trabalho científico. 6. ed. São Paulo: Editora Atlas, 2001.

Técnicas de pesquisa: planejamento e execução, amostragens e técnicas de pesquisa, elaboração, análise e interpretação de dados. 6. ed. 3 reimpr. São Paulo: Atlas, 2007.

MAXIMIANO, Antonio Cesar Amaru. Introdução à Administração. 7.ed.rev. e ampl.4.reimpr. São Paulo: Atlas, 2010. 
MEIRELLES, A. M. O planejamento estratégico no Banco Central do Brasil e a viabilidade estratégica em uma unidade descentralizada da autarquia: um estudo de caso. Dissertação (Mestrado em Administração) - CEPEAD/FACE/UFMG, Belo Horizonte: UFMG, 1995. 229 p.

MINAYO, M. C. S. Pesquisa social, teoria, método e criatividade. Petrópolis: Vozes, 2001.

MINTZBERG, H, QUINN, J.M. O processo de estratégia. 3 ed. Porto Alegre: Bookman, 2001.

MONTANA, Patrick; CHARNOV, Bruce H. Administração. 2.ed.[S.I]: Editora Saraiva, 2003

ROBBINS, Stephen Paul. Fundamentos do Comportamento Organizacional. Tradução técnica Reynaldo Marcondes. São Paulo: Pearson Prentice Hall, 2009.

SILVA, Reinaldo O. da. Teorias da administração. São Paulo: Pearson Prentice Hall, 2008.

TOMASI, Carolina; MEDEIROS, João Bosco. Comunicação empresarial. São Paulo: Atlas, 2007.

TORQUATO, Gaudêncio. Tratado de Comunicação organizacional e Política. Editora Thonson, Brasil, São Paulo, 2002.

VERGARA, Sylvia Constant. Projetos e Relatórios de Pesquisa em Administração.12. ed. São Paulo: Atlas, 2010.

Enviado: Setembro, 2019.

Aprovado: Outubro, 2019. 